\title{
Resident duty hours in Canada: a survey and national statement
}

\author{
Mark F Masterson ${ }^{1,2^{*}}$, Pankaj Shrichand ${ }^{1}$, Jerry M Maniate ${ }^{3}$ \\ From Duty Hours: Solutions Across Borders \\ Quebec City, Canada. 23 September 2011
}

\begin{abstract}
Physicians in general, and residents in particular, are adapting to duty schedules in which they have fewer continuous work hours; however, there are no Canadian guidelines on duty hours restrictions. To better inform resident duty hour policy in Canada, we set out to prepare a set of recommendations that would draw upon evidence reported in the literature and reflect the experiences of resident members of the Canadian Association of Internes and Residents (CAIR). A survey was prepared and distributed electronically to all resident members of CAIR. A total of 1796 eligible residents participated in the survey. Of those who responded, 38\% (601) reported that they felt they could safely provide care for up to 16 continuous hours, and 20\% (315) said that 12 continuous hours was the maximum period during which they could safely provide care $(n=1592)$. Eighty-two percent (1316) reported their perception that the quality of care they had provided suffered because of the number of consecutive hours worked ( $n=1598)$. Only 52\% (830) had received training in handover $(n=1594)$; those who had received such training reported that it was commonly provided through informal modelling. On the basis of these data and the existing literature, CAIR recommends that resident duty hours be managed in a way that does not endanger the health of residents or patients; does not impair education; is flexible; and does not violate ethical or legal standards. Further, residents should be formally trained in handover skills and alternative duty hour models.
\end{abstract}

\section{Introduction}

Increasing attention has been paid in recent years to resident fatigue caused by long consecutive hours of work and its implications for patient safety and the safety, well-being, and education of residents [1-3]. Recent editorials have highlighted the effects of sleep deprivation on all physicians, rather than only physicians-in-training $[4,5]$.

Although various resident duty hours are regulated in the United States and in member countries of the European Union [6,7], there are no national Canadian guidelines for resident duty hour restriction. Work hours are negotiated individually within each province. Quebec has recently negotiated a limit of 16 continuous hours of work [8]. Manitoba and the Maritime provinces have work-hour limits of 89 and 90 hours per week, respectively $[9,10]$, and several provinces limit

\footnotetext{
* Correspondence: mfmaster@interchange.ubc.ca

${ }^{1}$ Canadian Association of Internes and Residents, Ottawa, Canada Full list of author information is available at the end of the article
}

consecutive work hours to 24 , with adequate handover. Protracted periods of sleeplessness are common in Canadian training, and there is little experience with alternative scheduling models [11].

To better inform resident duty hour policy in Canada, we set out to prepare a set of recommendations that would draw upon evidence reported in the literature and reflect the experiences of resident members of the Canadian Association of Internes and Residents (CAIR).

\section{The evidence on resident fatigue}

A literature search was performed by one of the authors (PS) in conjunction with CAIR to identify literature that could inform the Canadian dialogue. Sources included a literature search used in the preparation of previous CAIR work [12], articles referred to us by provincial house staff organizations, residents with expertise in medical education, and PubMed and Google Scholar searches using combinations of the search terms "resident," "physician trainee," "duty hours," "work hours," 
"fatigue," and "Canada." "Related articles" links as provided by the respective search engines were also pursued. Key articles were selected and summarized by PS in conjunction with the Advocacy and Policy Committee of CAIR; their findings are summarized in Table 1.

\section{The CAIR duty hour survey}

CAIR surveyed its membership on issues related to work hours. Questions were prepared on the basis of the literature summary described above. A CAIR committee with representation from all residency years and from medical, surgical, and family medicine specialties identified gaps in the existing data in relation to the Canadian context and designed survey questions to assess these areas. These gaps included information about Canadian residents' current work hours, perceptions of the effect of work hours on patient safety, and training in patient safety and handover. The questions were then reviewed by the CAIR Board of Directors.

\section{Methods}

\section{Survey administration}

Resident members of CAIR or of any affiliated provincial housestaff organization (PHO) during the 2010-2011 academic year were eligible to participate in the survey. CAIR represents 7894 residents in Canada in the various provinces. These residents are represented locally by their PHOs, which are the Professional Association of Residents of British Columbia (PAR-BC), the Professional Association of Resident Physicians of Alberta (PARA), the Professional Association of Internes and
Residents of Saskatchewan (PAIRS), the Professional Association of Residents and Interns of Manitoba (PARIM), the Professional Association of Internes and Residents of Ontario (PAIRO), the Professional Association of Residents in the Maritime Provinces (PARI-MP), and the Professional Association of Internes and Residents of Newfoundland (PAIRN). Residents in Quebec were not included as they are not members of CAIR.

An invitation to participate in the survey was sent by email to residents through their respective PHOs beginning in the last week of June 2011; the invitation was open for five weeks, that is, until the end of July 2011. Two reminder notices were sent during that time. The invitation included a link to an online survey tool. The survey included basic demographic questions; responses were anonymized. An incentive prize was offered by random draw. The first page of the survey was an informed consent form.

\section{Data analysis}

The survey data were collected using an online platform, Survey Monkey, and were analyzed using descriptive statistics in Excel.

\section{Results}

We invited 7894 residents to participate in the survey. Of the 1831 individuals who responded, 1796 were eligible for inclusion (a response rate of $23 \%$ ). The 35 people who were not eligible indicated that they were not residents or members of a PHO. Respondents included residents in all years of training from medical schools in

Table 1 Selected summary of findings of the effects of resident fatigue

\begin{tabular}{|c|c|c|}
\hline Patient safety/care & Resident safety/wellness & Cognition/ability to learn \\
\hline $\begin{array}{l}\text { Of all resident errors, 5\%-36\% are caused by } \\
\text { fatigue [13]. }\end{array}$ & $\begin{array}{l}\text { First year residents reported a higher rate of } \\
\text { injury (exposure to contaminated bodily fluids, } \\
\text { percutaneous injuries) when fatigued [14]. }\end{array}$ & $\begin{array}{l}\text { The rate of falling asleep during lectures rose } \\
\text { significantly with the number of extended- } \\
\text { duration shifts worked in a given month [15]. }\end{array}$ \\
\hline $\begin{array}{l}\text { For residents working more than } 80 \text { hours a } \\
\text { week, the odds ratio of having a patient in the } \\
\text { last week who experienced an adverse event } \\
\text { was } 1: 8[16] \text {. }\end{array}$ & $\begin{array}{l}\text { Residents were most exposed to blood-borne } \\
\text { pathogens through needle punctures or cuts } \\
\text { during overnight work periods [17]. }\end{array}$ & $\begin{array}{l}\text { Staff physicians who were on call overnight had } \\
\text { reduced performance in standard cognitive } \\
\text { performance tests [18]. }\end{array}$ \\
\hline $\begin{array}{l}\text { A randomized controlled trial of duty hour } \\
\text { reduction found a significantly higher } \\
\text { occurrence of serious medical errors with } \\
\text { longer duty hours and less sleep [19]. }\end{array}$ & $\begin{array}{l}\text { Survey findings showed that residents were } 2.3 \\
\text { times more likely to be involved in a motor } \\
\text { vehicle crash after working an average of } 32- \\
\text { hour shifts [20]. }\end{array}$ & $\begin{array}{l}\text { One night without sleep reduced third-year } \\
\text { residents' performance on tests to the level of a } \\
\text { first-year resident [21]. }\end{array}$ \\
\hline $\begin{array}{l}\text { Residents made twice as many errors reading } \\
\text { ECGs after being awake for } 24 \text { hours [22]. }\end{array}$ & $\begin{array}{l}\text { Residents working shifts of more than } 24 \text { hours } \\
\text { were at greatly increased risk of an occupational } \\
\text { injury, a vehicle crash after work, and serious or } \\
\text { fatal medical errors [23]. }\end{array}$ & $\begin{array}{l}\text { Being awake for more than } 16 \text { consecutive } \\
\text { hours had an effect on cognitive performance } \\
\text { equivalent to a } 0.05 \%-0.10 \% \text { blood alcohol } \\
\text { concentration }[24-27] \text {. }\end{array}$ \\
\hline $\begin{array}{l}\text { Surgical residents who had been awake all } \\
\text { night made 20\% more errors in completing a } \\
\text { simulated laparoscopic surgical task than those } \\
\text { who had had a full night's sleep [28]. }\end{array}$ & $\begin{array}{l}\text { A survey of first- and second- year residents } \\
\text { found that those who reported obtaining less } \\
\text { than five hours of sleep per night were more } \\
\text { likely to report increased use of alcohol and } \\
\text { medications [29]. }\end{array}$ & \\
\hline
\end{tabular}


Canada outside of Quebec; 55\% were women. See additional file 1 for respondent demographics.

Residents reported working a median of 65 hours per week (interquartile range 60-80). Of those who responded to this question ( $\mathrm{n}=1592), 38 \%$ (601) reported that they felt they could "consistently provide safe, high quality patient care" for up to 16 continuous hours, and $20 \%$ (315) said they felt that 12 continuous hours was the maximum period during which they could safely provide care (Figure 1).

Eighty-two percent (1316) of respondents $(\mathrm{n}=1598)$ answered "yes" to the question, "Have you ever felt that the quality of care you provide patients has been compromised by the number of consecutive hours you have worked?" Those who replied "yes" were then asked to indicate how frequently they felt this happened; $30 \%$ (397) reported that they felt the quality of care they provided was compromised "Often" or "Very often," while only 19\% (244) responded that this "Seldom" happened (Figure 2).

To the question, "Does your program provide training on how work hours affect patient and resident safety?", $20 \%(312)$ of respondents $(\mathrm{n}=1597)$ responded in the affirmative, 56\% (893) in the negative, and 25\% (392) were unsure. Of the $20 \%$ who reported that their program did offer such training, only $58 \%$ indicated that they were able to participate.

To the question, "Have you received training during your residency on how to transfer patient care to another provider (i.e., handover)?", 52\% (830) responded "yes" ( $\mathrm{n}=1594)$. Of the $48 \%$ who had not received training in handover, $24 \%$ responded that they felt this absence of training had adversely affected their ability to provide safe, high-quality care to their patients, $32 \%$ said they were unsure, and $44 \%$ said they felt this did not affect their ability to provide safe, high-quality care.

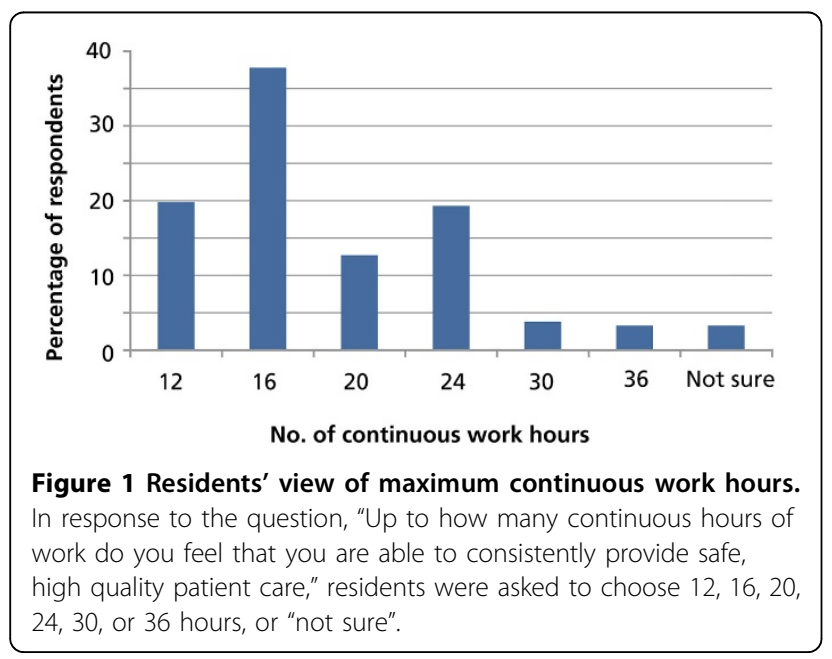

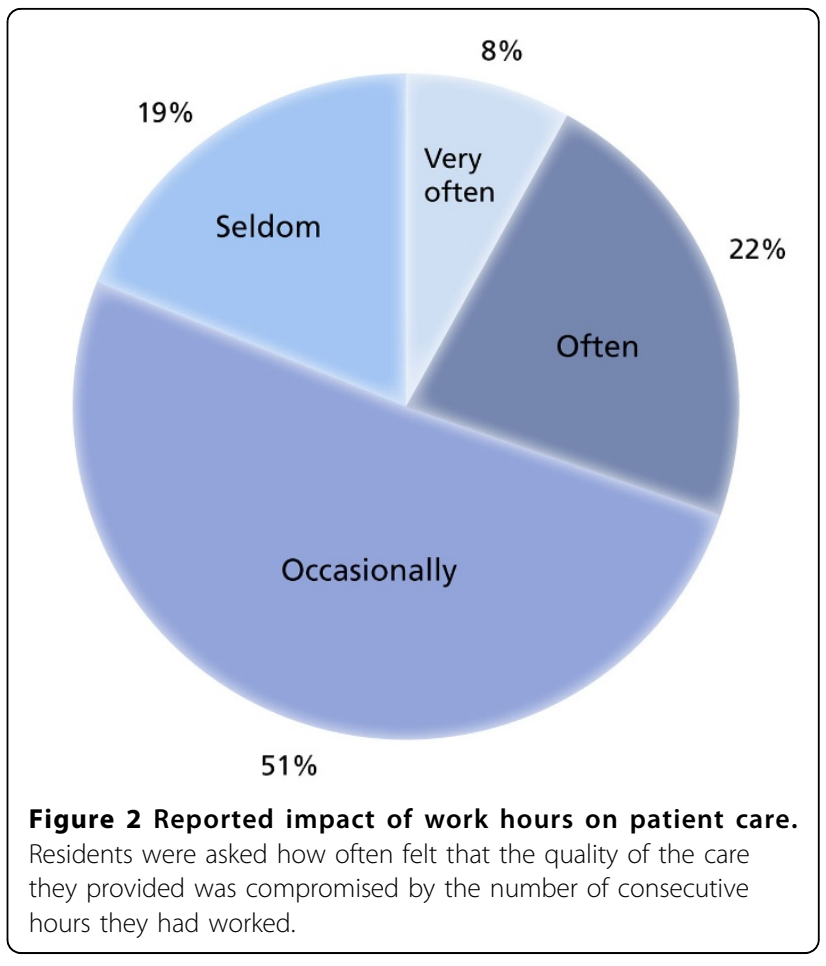

The handover training that was received was provided in a variety of formats (Figure 3). The vast majority of training was informal, delivered either by staff physicians or by senior residents. Of those who had received handover training $(\mathrm{n}=830), 73 \%$ felt that it had improved their ability to provide safe, high-quality care, $20 \%$ were unsure, and 7\% felt it did not help.

\section{Formulation of recommendations}

Results of the summarized literature and the survey were reviewed by the Advocacy and Policy Committee of CAIR. In consultation with CAIR staff and other CAIR committees, recommendations were developed,

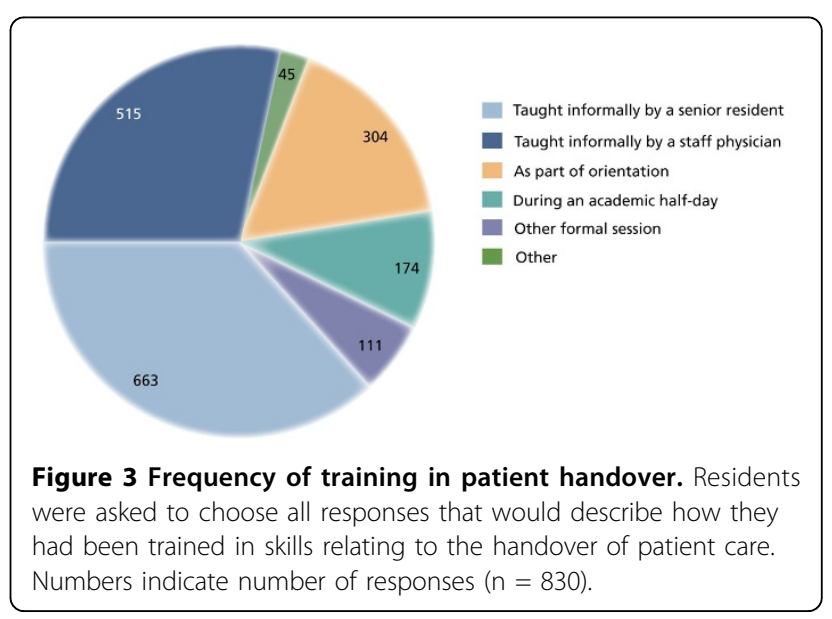


reviewed, amended, and approved by consensus by the CAIR Board of Directors.

\section{Recommendations}

In light of these survey data and the literature on resident fatigue, CAIR recommends that the following principles inform the development of policy and standards for resident duty hours in order to ensure patient safety, protect the safety and well-being of all physicians, and provide an optimal educational experience for medical residents [12]:

1. Residents' hours of work must be managed such that they do not in any way endanger their own or their patients' health. In particular, limits are required on the number of continuous uninterrupted hours that residents work at a time. In keeping with the evidence base, CAIR urges that all provinces and regions in Canada work towards a system that does not require residents to work more than 16 continuous uninterrupted clinical hours at a time, and that ensures adequate time in between work periods to eliminate the effects of sleep deprivation. This limitation will ensure residents' ability to provide safe, high-quality patient care while protecting their own personal health and safety.

2. Resident duty hours must be such as to allow for an optimal educational experience. Specifically, trainees' hours of work must not impair their ability to learn or to train others.

3. Residents must be formally trained in handover skills, i.e., the ability to transfer care appropriately when going off duty.

4. Resident duty hours should be flexible enough to accommodate the specific context of the resident's role and the service needs on particular rotations.

5. Where a violation of federal or provincial ethical, legislative, or legal standards has occurred, including but not limited to those related to the Canadian Charter of Rights and Freedoms, CAIR calls upon all stakeholders to address and remedy the situation as speedily as possible.

\section{Discussion}

This study does not include residents of Quebec and can thus not be generalized to all of Canada. Discussion among residents, both at CAIR and at the local level, has included a broader understanding and concern for the many issues that surround work hours [13]. These include whether 16 hours is truly a safe limit, or whether some other, shorter number of hours will be found to be optimal; the effect of shorter, possibly more frequent, work periods on resident and physician well- being; the effect of more frequent handovers on patient care; and the effect of chronic fatigue on decision making and learning [14].

One concern is the prolongation of training to enable residents to "see enough cases" and thus obtain adequate clinical exposure and opportunities for learning. Evidence from the literature on sleep deprivation and learning suggests that it is likely that shorter work hours will lead to improved learning and retention, and that residents can be trained "smarter and not harder" [15].

It should be noted that much of the discussion about resident duty hours is centred on traditional academic training centres. However, many residents are now training in non-traditional, community-based, rural or remote centres. It may be entirely appropriate to be oncall for prolonged periods in places where the frequency of active work is low and if there are provisions that enable residents to be relieved of responsibility in the event of an unexpectedly long period of continuous work. Training models will need to accommodate such circumstances.

Although more frequent handovers has been recognized in the literature as a consequence of duty hour restrictions that presents some risk to patient safety, little has been done to improve training in this area. It is remarkable that only $52 \%$ of the survey respondents indicated that they had received training in handover skills, while over $73 \%$ of those who had received even informal training felt it had improved their ability to provide safe, high-quality care.

\section{Conclusions}

Excessive work hours impair residents' self-reported ability to provide safe, high-quality care and this has affected over $82 \%$ of residents in the current system. This must change in a thoughtful manner that considers the best interest of patients. CAIR endorses the principles of protecting patient safety and resident well-being and safety through shorter shifts, optimizing the educational experience, training in appropriate handover techniques, ensuring flexibility for the specific context, and strictly adhering to existing ethical, legislative, and legal standards in the way we treat resident physicians.

\section{Additional material}

Additional file 1: Respondent demographics Residents in all years of training from medical schools in Canada outside of Quebec were invited to participate in the survey. The additional PDF file, titled Respondent Demographics, outlines the respondent demographics.

\section{Competing interests}

The authors declare that they have no competing interests. 


\section{Authors' contributions}

All authors contributed equally to the preparation of this paper.

\section{Acknowledgements}

We thank Dr. Meredith Guiliani for her review of the manuscript and the staff at CAIR for their efforts in carrying out the survey.

\section{Declarations}

Resources and secretariat support for this project was provided by the Royal College.

This article has been published as part of BMC Medical Education Volume 14 Supplement 1, 2014: Resident duty hours across borders: an international perspective. The full contents of the supplement are available online at http://www.biomedcentral.com/bmcmededuc/supplements/14/S1. This article was submitted in 2011 and peer reviewed in 2012. Final acceptance for publication as part of this supplement was in 2014.

Publication of this supplement was supported and funded by the Royal College of Physicians and Surgeons of Canada. The funding agency played no role in the design, in the collection, analysis and interpretation of data; in the writing of the manuscripts; and in the decision to submit the manuscript for publication. The articles have been through the journal's standard peer review process for supplements. The Supplement Editors declare that they have no competing interests.

\section{Authors' details}

${ }^{1}$ Canadian Association of Internes and Residents, Ottawa, Canada. ${ }^{2}$ Department of Anesthesiology, Pharmacology and Therapeutics, University of British Columbia, Vancouver, Canada. ${ }^{3}$ Department of Medicine, St. Joseph's Health Centre, University of Toronto, and Wilson Centre for Research in Education, Faculty of Medicine, University of Toronto, Toronto, Canada.

\section{Published: 11 December 2014}

\section{References}

1. Kelsall D: Must we keep depriving residents of sleep? CMAJ 2009, 180:1087.

2. Beluz J: Pan-Canadian standard needed for duty hours. Med Post 2011.

3. Cardwell M: State of the postgrad nation. Med Post 2011.

4. MacDonald NE, Hébert PC, Flegel K, Stanbrook MB: Working while sleepdeprived: not just a problem for residents. CMAJ 2011, 183:1689.

5. Nurok M, Czeisler CA, Lehmann LS: Sleep deprivation, elective surgical procedures, and informed consent. N Engl J Med 2010, 363:2577-2579.

6. Accreditation Council for Graduate Medical Education: Common Program Requirements., (approved 2013 June 9; effective 2013 July 1). [https://www. acgme.org/acgmeweb/tabid/429/ProgramandInstitutionalAccreditation/ CommonProgramRequirements.aspx].

7. European Commission: Working Conditions - Working Time Directive. (2003/88/EC) 2003 [http://ec.europa.eu/social/main.jsp? catld $=$ 706\&langld=en\&intPageld $=205$ ] .

8. Dussault C, Rousseau MC, Saad N, Carrier J: 16-hour call duty schedules: the Quebec experience. BMC Med Educ 2014, 14(S1):S10

9. PARIM: PARIM Contract: July 2008-June 2011. 2008 [http://www.parim. org/wp-content/uploads/2010/04/PARIM-Contract-July-2008-June-20111.pdf].

10. PARIMP: Collective Agreement: July 1, 2008-June 30, 2011. 2008 [http:// www.parimp.ca/images/pdf/PARI-MP\%202008-2011\%20Agreement.pdf].

11. Bell RH Jr: Alternative training models for surgical residency. Surg Clin N Am 2004, 84:1699-1711.

12. Cohen JS, Leung Y, Fahey M, Hoyt L, Sinha R, Cailler L, Kevin Ramchandar K, Martin J, Patten S: The happy docs study: a Canadian Association of Internes and Residents well-being survey examining resident physician health and satisfaction within and outside of residency training in Canada. BMC Research Notes 2008, 1:105.

13. Institute of Medicine: Resident Duty Hours: Enhancing Sleep, Supervision, and Safety. Washington (DC): National Academies Press;Ulmer C, Miller Wolman D, Johan MME 2009:

14. Ayas NT, Barger LK, Cade BE, Hashimoto DM, Rosner B, Cronin JW, Speizer FE, Czeisler CA: Extended work duration and the risk of selfreported percutaneous injuries in interns. JAMA 2006, 296:1055-1062.
15. Barger LK, Ayas NT, Cade BE, Cronin JW, Rosner B, Speizer FE, Czeisler CA: Impact of extended-duration shifts on medical errors, adverse events, and attentional failures. PLoS Med 2006, 3:e487.

16. Jagsi R, Kitch BT, Weinstein DF, Campbell EG, Hutter M, Weissman JS: Residents report on adverse events and their causes. Arch Intern Med 2005, 165:2607-2613

17. Parks DK, Yetman RJ, McNeese MC, Burau K, Smolensky MH: Day-night pattern in accidental exposures to blood-borne pathogens among medical students and residents. Chronobiology Int 2000, 17:61-70.

18. Robbins J, Gottlieb F: Sleep deprivation and cognitive testing in internal medicine house staff. West J Med 1990, 152:82-86.

19. Landrigan CP, Rothschild JM, Cronin JW, Kaushal R, Burdick E, Katz JT, Lilly CM, Stone PH, Lockley SW, Bates DW, Czeisler CA: Effect of reducing interns' work hours on serious medical errors in intensive care units. $N$ Engl J Med 2004, 351:1838-1848.

20. Barger LK, Cade BE, Ayas NT, Cronin JW, Rosner B, Speizer FE, Czeisler CA, Harvard Work Hours, Health, and Safety Group: Extended work shifts and the risk of motor vehicle crashes among interns. N Engl J Med 2005, 352:125-134.

21. Jacques CH, Lynch JC, Samkoff JS: The effects of sleep loss on cognitive performance of resident physicians. J Fam Pract 1990, 30:223-229.

22. Friedman RC, Bigger JT, Kornfield DS: The intern and sleep loss. N Engl J Med 1971, 285:201-203.

23. Lockley SW, Barger LK, Ayas NT, Rothschild JM, Czeisler CA, Landrigan CP, Harvard Work Hours, Health and Safety Group: Effects of health care provider work hours and sleep deprivation on safety and performance. Jt Comm J Qual Patient Saf 2007, 33(11 Suppl):7-18.

24. Arnedt JT, Owens J, Crouch M, Stahl J, Carskadon MA: Neurobehavioral performance of residents after heavy night call vs after alcohol ingestion. JAMA 2005, 294:1025-1033.

25. Dawson D, Reid K: Fatigue, alcohol and performance impairment. Nature 1997, 388:235.

26. Lamond N, Dawson D: Quantifying the performance impairment associated with fatigue. J Sleep Res 1999, 8:255-262.

27. Williamson AM, Feyer AM: Moderate sleep deprivation produces impairments in cognitive and motor performance equivalent to legally prescribed levels of alcohol intoxication. Occup Environ Med 2000, 57:649-655.

28. Taffinder NJ, McManus IC, Gul Y, Russell RC, Darzi A: Effect of sleep deprivation on surgeons' dexterity on laparoscopy simulator. Lancet 1998, 352:1191.

29. Baldwin DC Jr, Daugherty SR: Sleep deprivation and fatigue in residency training: Results of a national survey of first-and second-year residents. Sleep 2004, 27:217-223.

30. Eastridge BJ, Hamilton EC, O'Keefe GE, Rege RV, Valentine RJ, Jones DJ, Tesfay S, Thal ER: Effect of sleep deprivation on the performance of simulated laparoscopic surgical skill. Am J Surg 2003, 186:169-174.

31. Canadian Association of Internes and Residents (CAIR): Canadian Patient and Physician Safety and Wellbeing: Resident Duty Hours. Position paper on resident duy hours Ottawa: CAIR; 2012 [http://www.cair.ca/u/elibrary/ CAIR_EN_compressed\%20final\%20Apr\%204.pdf].

32. Cardwell M: State of the postgrad nation. Med Post 2011.

33. Cohen DA, Wang W, Wyatt JK, Kronauer RE, Dijk DJ, Czeisler CA, Klerman EB: Uncovering residual effects of chronic sleep loss on human performance. Science Trans/ Med 2010, 2:14ra3.

34. Australian Medical Association: Effects of Work Hours on Learning: Volumes 1 \& 2. 2004 [http://ama.com.au/node/3808].

doi:10.1186/1472-6920-14-S1-S9

Cite this article as: Masterson et al:: Resident duty hours in Canada: a survey and national statement. BMC Medical Education 2014 14(Suppl 1): s9. 